\title{
Congenital dilatation of the intrahepatic bile ducts with cholangiocarcinoma
}

\author{
P. J. GAllagher, R. R. Millis, AND M. J. MItChinson \\ From the Department of Pathology, University of Cambridge
}

SYNOPSIS Intrahepatic cholangiocarcinomas were found at necropsy in two previously reported cases of congenital dilatation of the intrahepatic bile ducts. The nature of the developmental abnormality is discussed and compared with other forms of biliary dilatation. Slow-flowing bile for i many years probably leads to cholangiocarcinoma.

Congenital dilatation of the intrahepatic bile ducts is a developmental abnormality which may present at any age. Localized ectasia of all or part of the intrahepatic biliary tree is responsible for the characteristic pattern of multiple communicating cystic spaces in the hepatic parenchyma (Caroli and Corcos, 1964). Approximately 25 cases are on record; of these reported cases two have come to necropsy in this department. In each a clinically undetected cholangiocarcinoma was discovered. In two of the other cases in the literature carcinomas were also found, one hepatocellular (Caroli and Corcos, 1964) and one cholangiocellular (Jones and Shreeve, 1970).

\section{Case Reports}

PATIENT NO. 1

A woman aged 36 was treated in 1945 for choledochus cyst by anastomosis of the cyst to the duodenum and cholecystectomy. In 1960 multiple cysts of the biliary tree were demonstrated during a barium meal examination when barium refluxed via the bile duct into the liver. Later stenosis of the common bile duct above the choledochal cyst led to ascending cholangitis; at operation the cyst was removed and a Roux loop of jejunum anastomosed to the massively dilated common hepatic duct. It was remarked that the main intrahepatic ducts were so dilated as to suggest that the cause was developmental abnormality rather than obstruction (Arthur and Stewart, 1964). Postoperative progress was satisfactory and jaundice subsided.

In 1967, subsequent to the clinical report, the patient was readmitted with pain in both shoulders, anorexia, and weight loss. She was not jaundiced. Two days later thrombosis of the deep veins of the Received for publication 16 June 1972. legs developed; this extended to the inferior vena cava and was followed by repeated pulmonary $\vec{c}$ embolism. Despite surgical evacuation of the thrombi $\mathbb{D}$ and plication of the inferior vena cava the patient's $\mathbb{\mathbb { D }}$ condition failed to improve and she died 15 days $\frac{3}{0}$ after admission.

At necropsy throughout the normal sized liver $\vec{\theta}$ there were massively dilated cylindrical bile ducis (up to $3.0 \mathrm{~cm}$ diameter) filled with semi-solit, yellow-grey material but no calculi. The intervenif parenchyma was widely infiltrated by neoplasm, almost confluent in the left lobe. Histologically this was a well differentiated cholangiocarcinoma (Fig. $\stackrel{\circ}{\square}$ 1). The dilated ducts had for the most part lost their $\cong$ epithelial linings but many sections showed villi $\overrightarrow{\overrightarrow{0}}$ protruding into the lumen. Interlobular bile ducts were normal microscopically. Fibrous tissue was not in excess but most of the larger ducts were intimately surrounded by chronic inflammatory cells. The neoplasm had metastasized to lymph nodes. The kidneys were unremarkable externally and microscopically. Death was due to pulmonary embolism.

PATIENT NO. 2

A 35-year-old man had first presented at the age of 3 with hepatomegaly and obstructive jaundice. $A \frac{D}{O}$ laparotomy revealed what was probably a greatly dilated common bile duct; this was drained ex- or ternally via a catheter. In a series of operations $N$ first the gall bladder and then a biliary fistula, which N was draining through the abdominal wall, were anastomosed to the duodenum. No further admissions to hospital were necessary until 1957 (aged $\stackrel{0}{\leftarrow}$ 21). In the interim the patient had suffered mild but $\stackrel{\circ}{\rightarrow}$ recurrent attacks of upper abdominal pain, fever, and jaundice. During this admission for an unusually severe bout of cholangitis dilated intrahepatic 


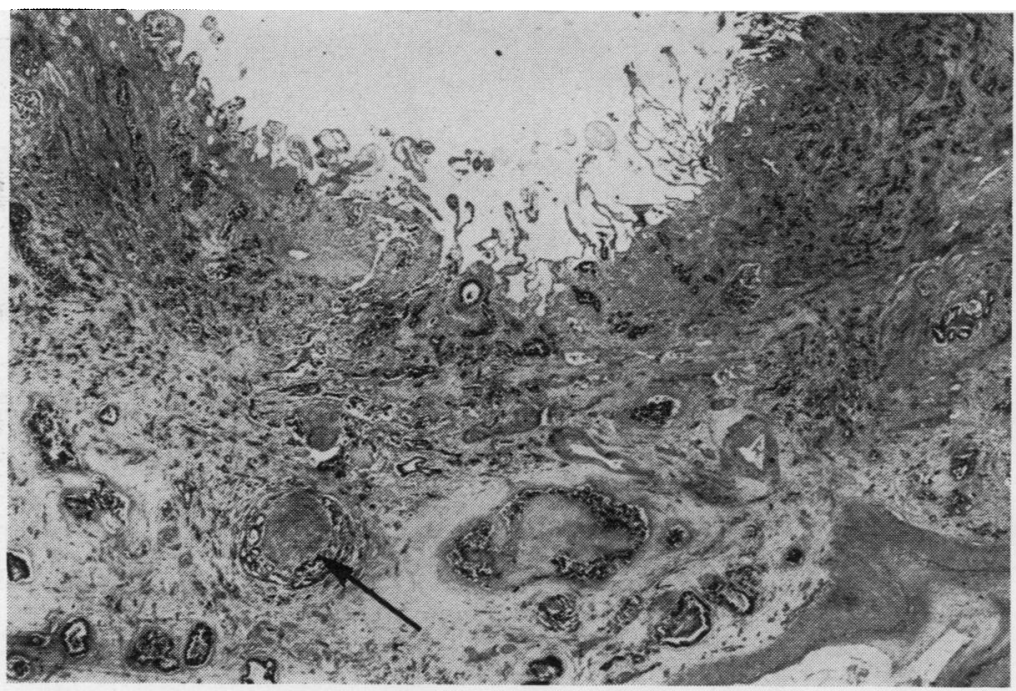

Fig. 1 Case 1.

Cholangiocarcinoma arising in the wall of a dilated intrahepatic bile duct $(H \& E$ $\times 30)$. A nerve showing perineural lymphatic permeation is arrowed. spaces were demonstrated during a barium meal examination.

Repeated attacks of severe cholangitis necessitated re-exploration in 1959. The common bile duct was anastomosed to a Roux loop of jejunum. The operation was not technically perfect and was slightly modified a year later after biliary stones had formed. For 10 years, until 1970, the patient's subjective symptoms were mild and he was able to work. Episodes of fever and jaundice then became more frequent and severe and were not contained by antibiotics. At a further operation the Roux loop was found to be stenosed and was refashioned (Kelly, 1971). Initial postoperative progress was good but cholangitis recurred, with deepening jaundice. Within six months ascites, ankle oedema, and hepatosplenomegaly had developed. There was clinical and biochemical evidence of liver failure and progress was downhill until death in 1971. At necropsy death was ascribed to haemorrhage from a chronic duodenal ulcer. The liver was enlarged (2750 grams). A postmortem cholangiogram, obtained by injecting the common bile duct retrogradely with a barium-gelatin mixture, showed a dilated intrahepatic tree (Fig. 2). Cystic spaces (up to $9.0 \mathrm{~cm}$ diameter) were discovered on sectioning the liver; many intrahepatic calculi were present (the largest $5.0 \mathrm{~cm}$ diameter). Neoplasm extensively infiltrated the right lobe, often surrounding the dilated ducts (Fig. 3). The Roux loop-common hepatic duct anastomosis was anatomically patent. The kidneys were unremarkable.

Microscopically the growth was a moderately well differentiated cholangiocarcinoma and had

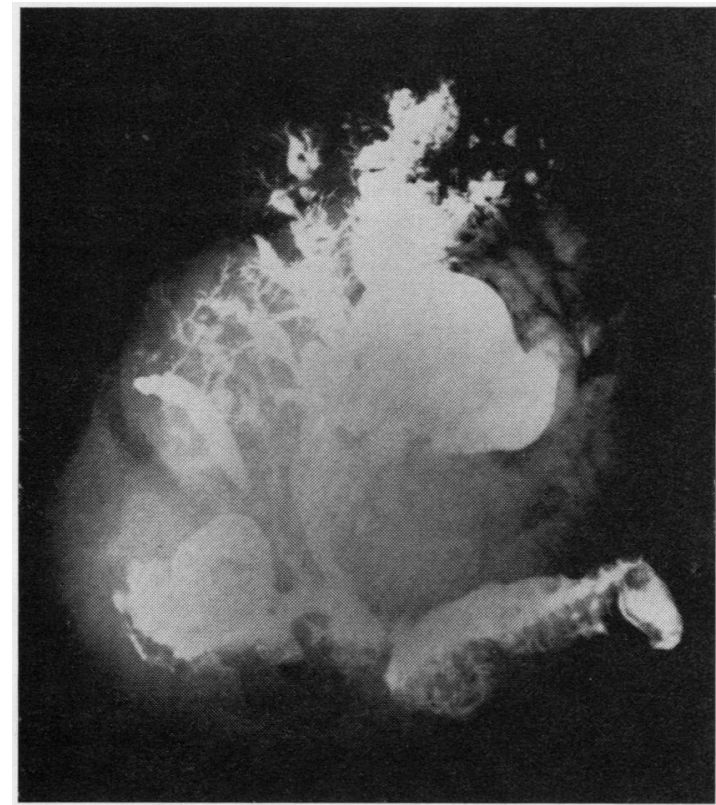

Fig. 2 Postmortem cholangiogram (case 2) showing the greater size and segmental nature of the dilatations compared to those secondary to obstruction (Fig. 3). Some reflux into the jejunum has occurred.

spread to the porta hepatis lymph nodes. Most of the larger ducts were cuffed by chronic inflammatory cells but there was little fibrosis. Many of the smaller cystic spaces, chiefly in the left lobe, showed no evidence of inflammation. 


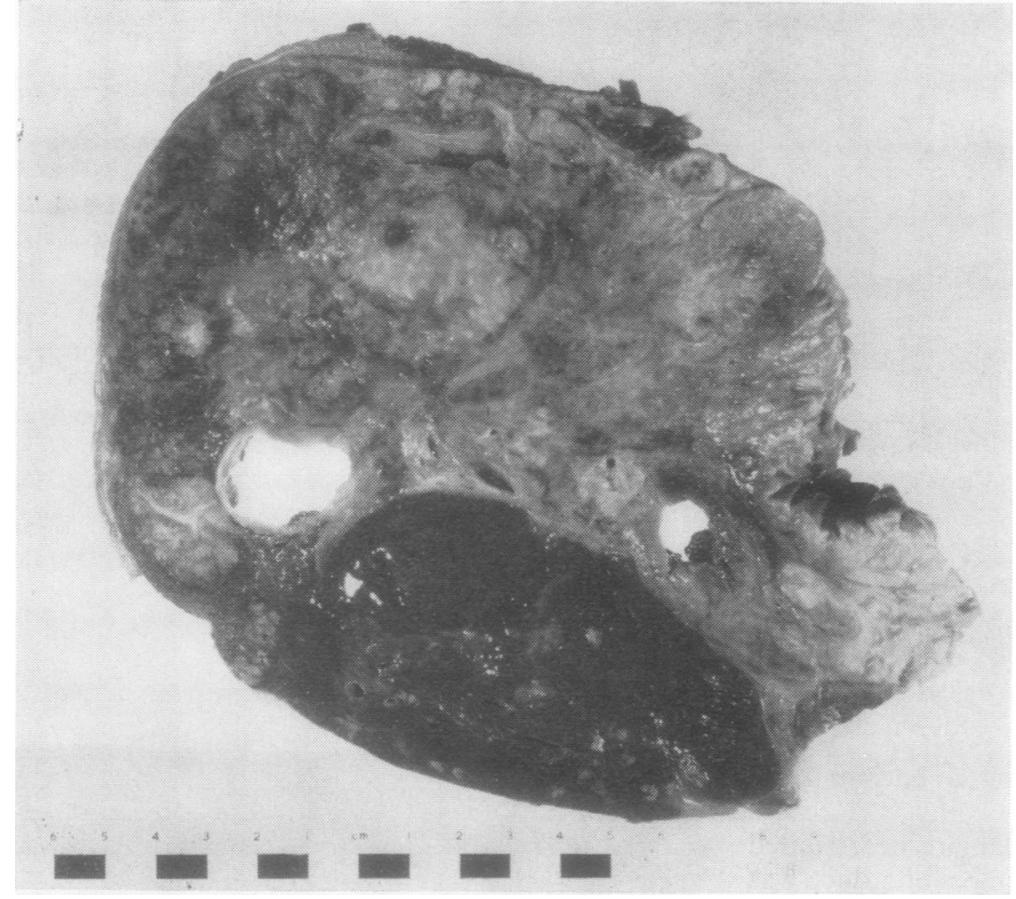

Fig. 3 A sagittal section of liver (case 2), showing dilated intrahepatic bile ducts के surrounded by carcinoma.

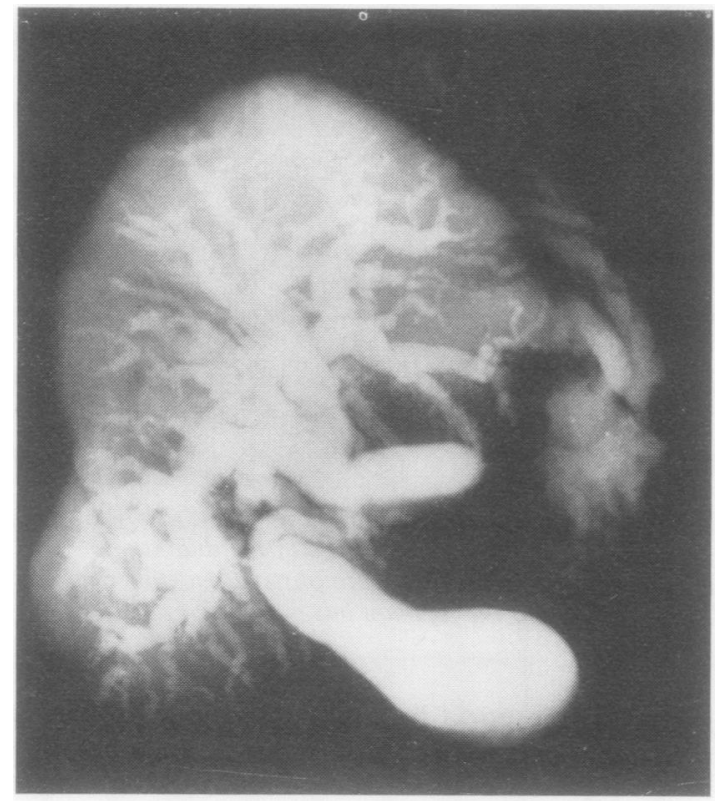

Fig. 4 Postmortem cholangiogram from a case of carcinoma of the head of the pancreas (cf. Fig. l).

\section{Discussion}

The form of biliary dilatation described in these two patients is rare. Essentially it differs from the dilatations seen as a result of acquired extrahepatic obstruction in the irregular, sometimes segmental distribution of the dilatations which can spare the interlobular ducts (Fig. 1 and Caroli and Corcos, 1964). The degree of dilatation seen in acquired obstruction may be great, but the whole biliary trees is involved uniformly (Fig. 4).

Although the condition described here is usuallyo called 'congenital' and may present early in life, at present the evidence is only sufficient to suggest thato it is developmental and the age of onset is unknown. Its developmental nature has been supported byor association with choledochal cyst (Gots and Zuidema,, 0 1970 and the present cases) or with renal tubular dilatations, the lack of obvious acquired cause, ando the bizarre distribution of the dilatations. Fibrosis in the neighbourhood of the dilatations may be con- $\frac{-}{8}$ spicuous (Caroli and Corcos, 1964) and the distinction@ from congenital hepatic fibrosis may occasionally be difficult. However, small biliary hamartomasō (von Meyenberg complexes) which are often seen in 


\begin{tabular}{|c|c|c|c|c|c|c|}
\hline Condition & $\begin{array}{l}\text { Approximate } \\
\text { No. Cases } \\
\text { Reported }\end{array}$ & $\begin{array}{l}\text { Cases of Cholangio- } \\
\text { carclnoma }\end{array}$ & Pathology & $\begin{array}{l}\text { Pathogenesis } \\
\text { (probable) }\end{array}$ & $\begin{array}{l}\text { von Mevenberg } \\
\text { Complexes }\end{array}$ & $\begin{array}{l}\text { Renal } \\
\text { Lesions }\end{array}$ \\
\hline $\begin{array}{l}\text { Congenital dilatation of the } \\
\text { intrahepatic bile ducts (1) }\end{array}$ & $\stackrel{25}{M}>\mathbf{F}$ & $\begin{array}{l}\text { Three intrahepatic } \\
\text { (6) }\end{array}$ & $\begin{array}{l}\text { Communicating cystic } \\
\text { dilatations intrahepatic } \\
\text { biliary tree with or } \\
\text { without fibrosis. Smallest } \\
\text { bile ducts may be normal. }\end{array}$ & $\begin{array}{l}\text { Developmental. } \\
\text { Ectasias of some } \\
\text { or all intrahepatic } \\
\text { ducts. }\end{array}$ & No & $\begin{array}{l}\text { Tubular } \\
\text { dilatations } \\
\text { also } \\
\text { ?polycystic } \\
\text { (1) }\end{array}$ \\
\hline $\begin{array}{l}\text { Congenital hepatic } \\
\text { fibrosis (2) }\end{array}$ & $\begin{array}{l}100 \\
F>M\end{array}$ & One intrahepatic (7) & $\begin{array}{l}\text { Distorted lobular } \\
\text { architecture; perilobular } \\
\text { fibrosis, bile duct } \\
\text { proliferation but no } \\
\text { regeneration. Hypoplasia } \\
\text { of small portal veins }\end{array}$ & $\begin{array}{l}\text { Developmental. } \\
\text { Excessive fibrosis } \\
\text { around von Meyen- } \\
\text { berg complexes. }\end{array}$ & Yes & $\begin{array}{l}\text { Often } \\
\text { polycystic }\end{array}$ \\
\hline Choledochal cyst (3) & $\begin{array}{l}400^{1} \\
F>M\end{array}$ & $\begin{array}{l}\text { Three intrahepatic } \\
(8-10) \text { Eight extra- } \\
\text { hepatic }(11-17)\end{array}$ & $\begin{array}{l}\text { Cystic dilatation of } \\
\text { common bile duct, } \\
\text { usually close to } \\
\text { duodenum }\end{array}$ & $\begin{array}{l}\text { Developmental; } \\
\text { weakness of common } \\
\text { bile duct wall plus } \\
\text { distal obstruction }\end{array}$ & No & None \\
\hline Polycysticliver (4) & $\begin{array}{l}400^{1} \\
F=M(5)\end{array}$ & $\begin{array}{l}\text { None definite } \\
\text { (see text) }\end{array}$ & $\begin{array}{l}\text { Non-communicating } \\
\text { cysts, do not contain } \\
\text { bile, no fibrosis. }\end{array}$ & $\begin{array}{l}\text { Developmental; } \\
\text { dilatation of von } \\
\text { Meyenberg com- } \\
\text { plexes }\end{array}$ & Yes & $\begin{array}{l}\text { Frequently } \\
\text { polycystic }\end{array}$ \\
\hline $\begin{array}{l}\text { Obstructive dilatation } \\
\text { of the intrahepatic bile } \\
\text { ducts }\end{array}$ & $\begin{array}{l}\text { Too common } \\
\text { to warrant } \\
\text { reporting }\end{array}$ & $\begin{array}{l}\text { Probably no } \\
\text { increased incidence }\end{array}$ & $\begin{array}{l}\text { Dilatation of intra- and } \\
\text { extrahepatic bile ducts, } \\
\text { often complicated by } \\
\text { inflammation. Smallest } \\
\text { ducts involved. }\end{array}$ & $\begin{array}{l}\text { Acquired; } \\
\text { secondary to } \\
\text { obstruction, eg, } \\
\text { stones, carcinoma, } \\
\text { or stricture }\end{array}$ & No & None \\
\hline
\end{tabular}

\section{Table Cases in the literature}

(1) Caroli and Corcos (1964), (2) Kerr et al (1961), (3) Alonso-Lej et al (1959), (4) Melnick (1955), (5) Moschcowitz (1906), (6) Authors' reports and Jones and Shrieve (1970), (7) Parker (1956), (8) Armanino (1964), (9) Dexter (1957), (10) George and Maingot (1962), (11) Irwin and Morison (1944), (12) Ferraris (1944), quoted by Alonso-Lej et al (1959), (13) Wilson et al (1956), (14) Macfarlane and Glenn (1967), (15) Fischer (1958), quoted by Macfarlane and Glenn (1967), (16) Thistlethwaite and Horwitz (1967), (17) Ashby (1964).

${ }^{1}$ New cases not generally reported; true numbers probably higher.

${ }^{2}$ Probably represent superfluous intrahepatic bile ducts which have not involuted; see (4) and (5)

cases of polycystic disease of the liver. (Melnick, 1955) and congenital hepatic fibrosis (Kerr et al, 1961) were seen in neither of the patients described above nor in cases previously reported.

Congenital cystic dilatation of the biliary tree and choledochal cyst are probably similar in that some partially obstructive lesion in early (probably intrauterine) life causes distension of part of the biliary tree. The extent and distribution of the dilatation would depend upon the position of the obstruction and the differential distensibility of parts of the biliary system at various stages of its development. The obstruction when recognizable seems to be stenosis due to peribiliary fibrosis. The cause of this fibrosis may be 'developmental' but intrauterine infections have not been excluded. Survival into adult life, without treatment, depends upon the obstructed segment allowing sufficient bile flow. Histories such as those described here show that even when bile drainage is adequate, the segmental dilatations are irreversible. The smallest ducts can be unaffected, showing no evidence of obstruction until some complication such as infection supervenes.

From the Table it can be seen that cholangiocarcinoma is more frequent in congenital dilatation of the intrahepatic ducts and choledochal cyst than in two other developmental conditions, polycystic disease of the liver and congenital hepatic fibrosis. It is in the first two conditions that bile stasis is a conspicuous feature. An obvious conclusion is that slow-flowing bile may over the years irritate the lining epithelium to cause cancer. Hyperplasia of the epithelium, seen in acquired obstruction in man (Karsner, 1943) and experimental animals (Gillman, Gilbert, and Spence, 1954;Stewart and Lieber, 1935), may be a precancerous lesion. Most acquired biliary obstructions are incompatible with long survival, thus perhaps explaining their relatively infrequent production of cholangiocarcinoma.

Cholangiocarcinoma may arise in the wall of a choledochal cyst, as has been mentioned. In three patients, however, intrahepatic cholangiocarcinomas were found with choledochal cyst (see Table); in all of these three reports the intrahepatic bile ducts were described as dilated, either segmentally or generally. While choledochal cyst can cause secondary obstructive dilatation it is tempting to speculate that some of these cases may have been examples of 'developmental' intrahepatic dilatation of long standing, analogous to the two patients in the present report. 
Malignant change has also been described in three 'congenital liver cysts'. In one of these the cyst communicated with the biliary system and was probably similar to the present cases (Shiewe, Baudisch, and Ehrhardt, 1968). The precise nature of the cysts in the other two cases was not clear (Willis, 1943; Richmond, 1956). Characteristically in true polycystic disease of the liver the cysts are not communicating and do not contain bile; we have not been able to find a report of carcinoma arising in this disease.

We find it difficult to escape the conclusion that any condition in which bile duct epithelium is exposed to slow-flowing bile for long periods is likely to predispose to cholangiocarcinoma.

We are grateful to the Department of Medical Photography, Addenbrooke's Hospital, for the figures.

References

Alonso-Lej, F., Rever, W. B., Jr., and Pessagno, D. J. (1959). Congenital choledochal cyst, with a report of two and an analysis of ninety-four cases. Int. Abstr. Surg., 108, 1-30.

Armanino, L. P. (1946). Idiopathic dilatation of the common bile duct with coexistent primary hepatic carcinoma. Ann. intern. Med., 24, 715-726.

Arthur, G. W., and Stewart, J. O. R. (1964). Biliary cysts. Brit. J. Surg., $51,671-675$.

Ashby, B. S. (1964). Carcinoma in a choledochus cyst. Brit. J. Surg., 51, 493-496.

Caroli, J., and Corcos, V. (1964). La dilatation congénitale des voies biliaires intrahépatiques. Rev. méd-chir. Mal. Foie, 39, 1-70.

Dexter, D. (1957). Choledochal cyst with carcinoma of the intrahepatic bile ducts and pancreatic ducts. Brit. J. Cancer, 11, 18-25.

Ferraris, L. V., Navarro, A., and Escargiel (1944). Dilatación congénita del hepatocolédoco y adenocarcinoma. Bol. Soc. Cirúg. Rosario, 5, 21.
Fischer, H. G. (1958), Primäres Karzinom in der Wand einer angeborenen zystischen Gallengangserweiterung (sog. Hepatikuszyste). Zbl. Chir., 83 1234-1241.

George, P. A., and Maingot, R. (1962). Choledochus cyst associated with carcinoma in the liver. Brit. J. Surg., 50, 339-341.

Gillman, J., Gilbert, C., and Spence, I. (1954). Some factors regulating the structural integrity of the intrahepatic biliary ducts with special reference to primary carcinoma of the liver and vitamin A. Cancer (Philad.), 7, $1109-1154$.

Gots, R. E., and Zuidema, G. D. (1970). Dilatation of the intrahepatic bile ducts in a patient with a choledochal cyst. Amer. J. Surg., 119, 726-728.

Irwin, S. T., and Morison, J. E. (1944). Congenital cyst of the common bile-duct containing stones and undergoing cancerous change. Brit. J. Surg., 32, 319-320.

Jones, A. W., and Shreeve, D. R. (1970). Congenital dilatation of the $\vec{\odot}$ intrahepatic bile ducts with cholangiocarcinoma. Brit. med. J., 2, 277-278.

Karsner, H. T. (1943). Morphology and pathogenesis of hepatic cirrhosis. Amer. J. clin. Path., 13, 569-606.

Kelly, M. J. (1971). Case of Caroli's disease. Brit. med. J., 4, 407.

Kerr, D. N. S., Harrison, C. V. Sherlock, S., and Walker, R. M (1961). Congenital hepatic fibrosis. Quart. J. Med., 30,91-117. G

Macfarlane, J. R., and Glenn, F. (1967). Carcinoma in choledochal cyst. J. Amer. med. Ass., 202, 1003-1006.

Melnick, P. J. (1955). Polycystic liver; analysis of seventy cases. $\stackrel{\cap}{\mathbb{A}}$ Arch. Path., 59, 162-172.

Moschcowitz, E. (1906). Non-parasitic cysts (congenital) of the liver, with a study of aberrant bile ducts. Amer. J. med. Sci., 131,674699.

Parker, R. G. F. (1956). Fibrosis of the liver as a congenital anomaly. J. Path. Bact., 71, 359-368.

Richmond, H. G. (1956). Carcinoma arising in congenital cysts of the liver. J. Path. Bact., 72, 681-683.

Schiewe, R., Baudisch, E., and Ehrhardt, G. (1968). Angeborene intrahepatische Gallengangszyste mit Steinbildung und malinger Entartung. Bruns'Beitr. klin. Chir., 216, 264-271.

Stewart, H. L., and Lieber, M. H. (1935). Ligation of the commg bile duct in the cat. Arch. Path., 19, 34-46.

Thistlethwaite, J. R., and Horwitz, A. (1967). Choledochal cyst follow by carcinoma of the hepatic duct. Sth. med. J. (Bgham, Alaळ 60, 872-874.

Willis, R. A. (1943). Carcinoma arising in congenital cysts of the liver J. Path. Bact., 55, $492-495$.

Wilson, F. D., Morrissey, G. E. and McConnell, R. W. (1956). Bile duct cyst with malignant degeneration. J. Iowa med. Soc., 46. 72-78. 